\title{
The Change in Growth Phase of Luja Plants (Peristrhophe bivalvis Merrill) Due to Differences in Light Intensities and Stem Cuttings
}

\author{
Rima Melati ${ }^{1, *}$, Nurul Aini ${ }^{2}$, Helda Sabban ${ }^{1}$ \\ ${ }^{I}$ Department of Agrotechnology, Faculty of Agriculture Khairun University, Ternate, Indonesia \\ ${ }^{2}$ Faculty of Agriculture University of Brawijaya Malang, Indonesia \\ *Corresponding author.Email: rima_tafure@yahoo.com
}

\begin{abstract}
The change in every phase of plant growth can be seen from the growth of plant organ every week. Cutting materials used can influence the growth phase in different light environmental conditions. The research aimed to find out light intensities and part of stem cuttings influencing the change in growth phase of Luja plants. Light intensities treatment consisted of $100 \%, 65 \%, 35 \%$, and $15 \%$ and planting materials consisted of basal and tip cuttings; therefore, there were 8 treatment combinations with three repetitions. Design model used was split plot design and continued with Duncan test that analyzed using SAS 9.3 program. The research results indicated that there was an interaction between light intensities and cuttings on variables of number of leaves and leaf area. The influence of light intensities and cuttings, individually, was indicated on variables of number of leaves, number of branches, canopy diameter and leaf area. The light intensity of $35 \%$ was a good growth environment condition for Luja plant; whereas the good cutting was tip cutting thus Luja is considered as a canopy-tolerant plant.
\end{abstract}

Keywords: Luja, light, cutting, growth phase

\section{INTRODUCTION}

Economic-valued wild plants exploration needs to be developed at present to support local as well as national industries. Luja plant is a wild plant potential for textile dyes [1]. There are minimum researches on the cultivation aspect of luja plant; thus, this research can be used as a database for further cultivation development. This research aims to find out the growth environment condition with optimal light and cutting materials to encourage growth based on changes in plant organs in every growth phase. Light intensity differences could influence growth in initial nursery [2]. Cutting methods are still relevant to study and have superiorities of inheriting the parent properties, producing tiller in bulk and maintaining scarce plant population rapidly. Several previous studies explained that one of factors influencing plant pigment produced was light $[3,4]$ including plant quantity and quality [5]. Tip cutting is suggested for plant propagation, especially in several plants such as Stevia Rebaudiana Bertoni that is stimulated by hormones, Alstonia scholaris (L.) R. Br by considering cutting position and sweet potato [6]. The use of Plectranthus vettiveroides tip cutting with 1-6 nodules is the best compared to basal cutting since it influences plant height, number of leaves, number of branches, leaf area and plant fresh weight of plants planted in light intensity condition of 3000-6000 lux [7].

Analysis of plant growth and biomass increase during growth phases depends highly on light received by the plants; thus, photosynthesis production can be estimated through biomass production approach. Growth environment stimuli, such as light, play role in the formation of pigments and specific leaf area $[8,9]$ hence, it can be used as an indicator of growth and biomass accumulation that depends on plant ability to absorb light for photosynthesis and pigment formation [10]. Biomass allocation in every Barberis darwinii organ during nursery phases differs in different shading condition [11]. Centtela asantica has the highest biomass in $30 \%$ shade; however, it total chlorophyll is the highest in $70 \%$ shade $[12,13]$. In Balanites aegyptiaca, on the contrary, growth environment with at different intensities of $25 \%-100 \%$ has no influence on leaf area during initial growth [2].

\section{METHODS}

Field experiment research was conducted at Dadaprejo Village Batu City East Java at an altitude of $450 \mathrm{~m}$ a.s.1 and observation was undertaken at the Laboratory of Environmental Resources Faculty of Agriculture Brawijaya University from October 2018 to January 2019. Treatments consisted of two factors - namely, light intensities (I) and cutting planting materials (S). The light intensities consisted of $100 \%\left(\mathrm{I}_{0}\right), 65 \%\left(\mathrm{I}_{1}\right), 35 \%\left(\mathrm{I}_{2}\right)$ and $15 \%\left(\mathrm{I}_{3}\right)$; thus resulted in 8 (eight) total treatment. Treatment combination tested included $\mathrm{I}_{0} \mathrm{~S}_{1}$ (Light intensity of $100 \%+$ basal cutting), $\mathrm{I}_{0} \mathrm{~S}_{2}$ (light intensity of $100 \%+$ tip cutting), $\mathrm{I}_{1} \mathrm{~S}_{1}$ (light intensity of $65 \%+$ basal cutting), $\mathrm{I}_{1} \mathrm{~S}_{2}$ (light intensity of $65 \%+$ tip cutting), $\mathrm{I}_{2} \mathrm{~S}_{1}$ (light intensity of $35 \%+$ basal cutting), $\mathrm{I}_{2} \mathrm{~S}_{2}$ (light 
intensity of $35 \%+$ tip cutting), $\mathrm{I}_{3} \mathrm{~S}_{1}$ (light intensity of $15 \%$ + basal cutting), $\mathrm{I}_{3} \mathrm{~S}_{2}$ (light intensity of $15 \%+$ tip cutting). The light simulation used two types of net: net A (called waring with a hole size of $0.5 \times 0.5 \mathrm{~cm}$ ) and net B (para net $60 \%$ ). Light intensity of $100 \%=$ without net $\left(\mathrm{I}_{0}\right)$, light intensity of $65 \%=1$ sheet of net $A\left(\mathrm{I}_{1}\right)$, light intensity of $35 \%=1$ sheet of net $\mathrm{A}+1$ sheet of net $\mathrm{B}\left(\mathrm{I}_{2}\right)$ and light intensity of $15 \%=2$ sheets of net $\mathrm{B}\left(\mathrm{I}_{3}\right)$. A basal cutting $\left(\mathrm{S}_{1}\right)$ was the basal part of secondary branches cut into 4 (four) sections and tip cutting $\left(\mathrm{S}_{2}\right)$ was secondary branch tips consisted of 4 (four) sections counted from the tip. Cuttings planting was done by inserting 1 (one) section into growing media; thus leaving 3 (three) sections above the ground. The nursery was conducted in shaded areas for 4 (four) weeks and then the plants were transferred to planting areas according to the tested treatments. Initial observation was performed two weeks after treatments (w.a.t) and the next observation was conducted for once every two weeks during the growth period (12 weeks). Research variables consisted of a number of leaves, number of branches, canopy diameter and leaf area. The research design used was split plot design consisted of 8 (eight) treatments with 3 (three) repetitions. The variance analysis result was followed up by Duncan test in a confidence level of 0.05 using SAS 9.3 software.

\section{RESULTS AND DISCUSSION}

\section{a. Number of Leaves}

The research result indicated that interaction between light intensity and luja plant cuttings were observed only at the age of 2 (two) weeks after transplanting (Figure 1). The highest number of leaves was found at light intensity of $65 \%$ with basal part cutting and light intensity of $15 \%$ with tip cutting and both were significantly difference to other treatments. Whereas, plants originated from tip cuttings at light intensity of $100 \%$ were equal to those plants at light intensity of $65 \%$ with tip cutting and light intensity of $35 \%$ with both types of cutting. Plants in the same light intensity but different cuttings indicated a significant differences, except for a light intensity of $35 \%$. The number of leaves produced in two weeks after transplanting was the accumulation of number of leaves during nursery and initial adaptation to a full-light exposed and shaded environment. Adaptation process in different environment lasted at the age of 2 (two) weeks after transplanting despite the similarity in adjustment of planting materials from the cuttings, in which basal and tip cuttings exhibited similar adaptation ability. That there was no influence of tip, middle, and basal cuttings of Ficus carica plant on number of leaves at the age of 2 (two) weeks after planting [14], whereas Plectranthus vettiveroides (K.C.Jacob) required light intensity of 50\% with tip cutting that had more leaves [7] and shade of 55\% [15].

A significant different influence of light intensity found in observation at $4,6,8$ and 10 weeks after treatmens (w.a.tr), except at 12 w.a.tr. Part of cuttings that had a significant influence on the number of leaves was at 4 (w.a.tr) and no influence found for the following observation (Table 1). The highest number of leaves found in treatment with the light intensity of $65 \%$ and $35 \%$ compared to those plants exposed with light of $15 \%$. However, it had a similarity to those plants exposed with full light $(100 \%)$ at 4 w.a.tr. At the sixth and eighth w.a.t, plants exposed with light of $15 \%$ had less leaves and it was significantly different to those plants exposed with $35 \%$ $100 \%$ of light. The condition took place until the end of observation period. Luja grew in a shaded environment experienced a large increase in the number of leaves during vegetative phase compared to those plants exposed with full light $(100 \%)$. On the contrary, entering the generative phase, luja plants undergone a growth pressure in the grow environment with full light during initial growth indicated by the less number of leaves. Plant adaptation ability in a light condition of $100 \%$ experienced a change in the second month after transplanting. Plant character to absorb available light depends on its genetic properties. In this case, plant maximizes light received to produce carbohydrate thus encourages the addition of apical meristem to form shoots and leaves.

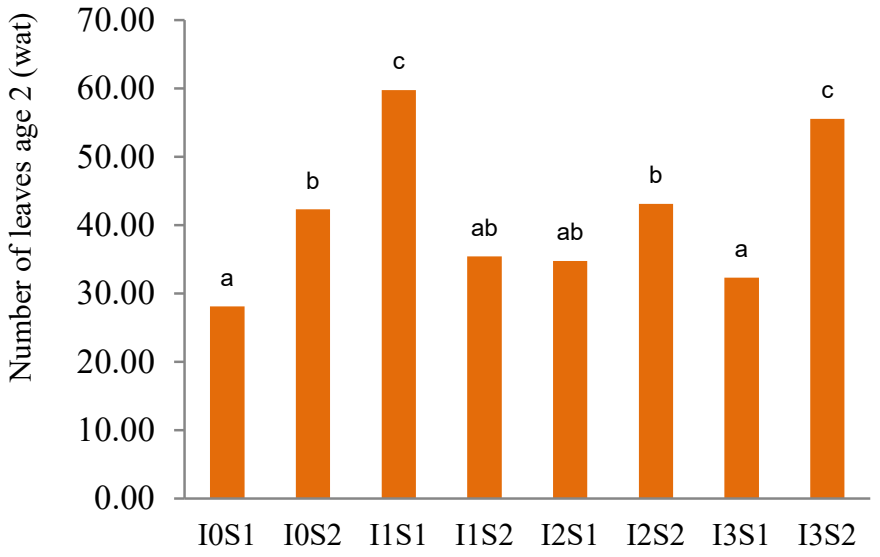

Figure 1. Influence of interaction between light intensity and planting materials on number of leaves at the age of 2 (two weeks) after transplanting; $\mathrm{I}_{0} \mathrm{~S}_{1}$ (Light intensity of $100 \%+$ basal cutting), $\mathrm{I}_{0} \mathrm{~S}_{2}$ (light intensity of $100 \%+$ tip cutting), $\mathrm{I}_{1} \mathrm{~S}_{1}$ (light intensity of $65 \%+$ basal cutting), $\mathrm{I}_{1} \mathrm{~S}_{2}$ (light intensity of $65 \%+$ tip cutting), $\mathrm{I}_{2} \mathrm{~S}_{1}$ (light intensity of $35 \%+$ basal cutting), $\mathrm{I}_{2} \mathrm{~S}_{2}$ (light intensity of $35 \%+$ tip cutting), $\mathrm{I}_{3} \mathrm{~S}_{1}$ (light intensity of $15 \%+$ basal cutting), $\mathrm{I}_{3} \mathrm{~S}_{2}$ (light intensity of $15 \%+$ tip cutting) 
Table 1. Influence of Light Intensity and Planting Materials on Number of Leaves at 4, 6, 8 and 10 weeks after treatment

\begin{tabular}{|l|c|l|l|l|}
\hline \multirow{2}{*}{$\begin{array}{l}\text { Light } \\
\text { Intensity }\end{array}$} & \multicolumn{5}{|c|}{ Mean of Number of Leaves } \\
\cline { 2 - 5 } & $\mathbf{4}$ & \multicolumn{4}{|c|}{$\mathbf{6}$} & \multicolumn{1}{c|}{$\mathbf{8}$} & \multicolumn{1}{|c|}{$\mathbf{1 0}$} \\
\cline { 2 - 5 } & \multicolumn{4}{|c|}{ w.tr } \\
\hline $100 \%$ & $76.28^{\mathrm{ab}}$ & $255.72^{\mathrm{b}}$ & $257.67^{\mathrm{b}}$ & $284.17^{\mathrm{b}}$ \\
\hline $65 \%$ & $94.50^{\mathrm{b}}$ & $216.67^{\mathrm{b}}$ & $252.28^{\mathrm{b}}$ & $269.50^{\mathrm{b}}$ \\
\hline $35 \%$ & $94.45^{\mathrm{b}}$ & $244.55^{\mathrm{b}}$ & $246.00^{\mathrm{b}}$ & $211.33^{\mathrm{a}}$ \\
\hline $15 \%$ & $68.00^{\mathrm{a}}$ & $168.78^{\mathrm{a}}$ & $211.00^{\mathrm{a}}$ & $193.61^{\mathrm{a}}$ \\
\hline $\begin{array}{l}\text { Planting } \\
\text { materials }\end{array}$ & & & & \\
\hline $\begin{array}{l}\text { Basal } \\
\text { cuttings }\end{array}$ & $72.75^{\mathrm{a}}$ & $\mathrm{ns}$ & $\mathrm{ns}$ & $\mathrm{ns}$ \\
\hline $\begin{array}{l}\text { Tip } \\
\text { cuttings }\end{array}$ & $93.86^{\mathrm{b}}$ & $\mathrm{ns}$ & $\mathrm{ns}$ & $\mathrm{ns}$ \\
\hline
\end{tabular}

Note: Numbers followed by the same letter are insignificantly different based on Duncan test at a level of 0.05 ; week after treatments (w.a.tr), non-significant (ns).

There was a difference in the number of leaves in several flower plants related to lighting, chrysanthemum plant had less number of leaves if light was under 55\% [16], whereas carnation flower with and without shade had the same number of leaves at 2-6 weeks after transplanting [17]. Tip cuttings had the highest number of leaves compared to basal cuttings at 2 w.a.t since plants that had been cut for tip cuttings continued to grow after the cuttings, whereas adventive shoots on basal cuttings emerged at 5-7 days after cuttings. The condition influenced the number of leaves formed and it was supported by more apical meristem in the tip. The research result is similar to those in Stevia Rebaudiana Bertoni plant where tip cuttings were faster in forming new grow tissues after cuttings [6] and sweet potato tip cuttings grew faster compared to basal cuttings [18].

\section{b. Number of Branches}

The interaction between light intensity and planting materials originated from cuttings had no influence on the formation of luja plant branches. On the contrary, separated treatment had influence on the number of branches formed. Light intensity influenced the number of branches in the initial growth until the end of observation (2-12 weeks after treatments). The light intensity of $65 \%$ and $35 \%$ produced the highest number of branches compared to light intensity of $100 \%$ and $15 \%$. Plants exposed to light of $100 \%$ experienced an increase in the number of branches at the sixth and eighth w.a.t until the end of observation, although it was insignificantly different to light treatment of $65 \%$ and $35 \%$ (Table 2). Optimum light intensity will trigger shoot and branch growth since it is supported by photosynthetic metabolism occurred by maximizing primary metabolic for apical meristem enlargement. Tip cuttings had rapid apical meristem growth and triggered new shoot growth; hence, produced more branches. Luja plants could optimally growth at light intensity between $35 \%$ and $65 \%$, whereas the growth was not maximal in minimum light condition. It is similar to Dendrobium candidum plants placed in low light $(95 \%)$ and carnation flower in shaded condition of $20 \%[19,17]$. Every plant has its own ability in receiving light and it is different for every plant type. For example, Mucuna bracteata D.C plant that originated from cuttings experiences a decreasing growth in nursery phase if in a shaded condition of $25 \%-75 \% \quad[20], \quad w$ hereas Cryptostegia madagascariensis Bojer in a no-shade environment has faster branch formation and large number of branches compared those in shade of $30 \%, 50 \%$ and $70 \%[21]$.

Table 2. Influence of Light Intensity and Planting Materials on Number of leaves at 2-12 weeks after treatment

\begin{tabular}{|c|c|c|c|c|c|c|}
\hline \multirow{3}{*}{ Light Intensity } & \multicolumn{6}{|c|}{ Mean of Number of Leaves } \\
\hline & 2 & 4 & 6 & 8 & 10 & 12 \\
\hline & \multicolumn{6}{|c|}{ w.a.tr } \\
\hline $100 \%$ & $7.45^{\mathrm{a}}$ & $13.02^{a b}$ & $44.00^{\mathrm{c}}$ & $53.44^{b}$ & $60.11^{b}$ & $56.94^{b}$ \\
\hline $65 \%$ & $11.01^{\mathrm{b}}$ & $15.61^{\mathrm{bc}}$ & $34.61^{\mathrm{b}}$ & $48.50^{\mathrm{ab}}$ & $56.61^{b}$ & $56.70^{b}$ \\
\hline $35 \%$ & $10.23^{b}$ & $17.06^{\mathrm{c}}$ & $32.61^{\mathrm{ab}}$ & $47.22^{\mathrm{ab}}$ & $48.33^{\mathrm{ab}}$ & $51.17^{\mathrm{ab}}$ \\
\hline $15 \%$ & $7.00^{\mathrm{a}}$ & $11.55^{\mathrm{a}}$ & $24.55^{\mathrm{a}}$ & $40.22^{\mathrm{a}}$ & $37.55^{\mathrm{a}}$ & $43.61^{\mathrm{a}}$ \\
\hline \multicolumn{7}{|l|}{ Planting Materials } \\
\hline Basal cuttings & $6.61^{\mathrm{a}}$ & $11.78^{\mathrm{a}}$ & ns & ns & ns & ns \\
\hline Tip cuttings & $11.22^{b}$ & $16.83^{b}$ & ns & ns & ns & ns \\
\hline
\end{tabular}

Note: Numbers followed by the same letter are insignificantly different based on Duncan test at a level of 0.05 ; week after treatments (w.a.tr), non-significant (ns). 


\section{c. Canopy Diameter}

The variance analysis result suggested that there was no interaction between light intensities and cutting planting materials of luja plant at 2-12 w.a.t; however, only single factor influence that was visible. The influence of light intensities on canopy diameter occurred at 2, 4 and 12 w.a.t where the light intensity of $65 \%, 35 \%$, and $15 \%$ were insignificantly different to light intensity of $100 \%$ in observation at 2 and 4 w.a.t. Moreover, observation at 12 w.a.t indicated that light intensity of $35 \%$ had wider canopy diameter than other treatments, except for plants located in a light intensity of $15 \%$ (Table 3 ). It was assumed that a wide canopy diameter in shaded plant condition is one of plant adaptation mechanism for efficient use of light. The light intensity of $35 \%$ was the optimum intensity to support luja plant growth. The condition is different from chrysanthemum plant that requires higher light intensity which is $75 \%$.

Wide canopy diameter is also assumed as the occurrence of etiolation due to a minimum light received by plant and it is similar to those found Curcuma zedoaria Christm. with $25 \%$ shade [22], thus it will influence plant canopy. The influence of planting materials with cuttings was seen in the initial growth ( 2 w.a.tr), where tip cuttings had a wider diameter compared to basal cuttings. Apical meristem growth process and elongation in tip cuttings were faster and easier; thus, its growth process continued from the beginning of cuttings without any dormant phase or adaptation during nursery phase that triggered by plant hormones availability such as auxin located in the tip part [18].

Table 3. Influence of Light Intensity and Planting Materials on Canopy Diameter at 2, 4 and 12 weeks after treatment (w.a.tr)

\begin{tabular}{|l|l|l|l|}
\hline \multirow{2}{*}{ Light Intensity } & \multicolumn{3}{|c|}{ Mean of Canopy Diameter (cm) } \\
\cline { 2 - 4 } & 2 w.a.tr & 4 w.a.tr & 12 w.a.tr \\
\hline $100 \%$ & $25.95^{\mathrm{a}}$ & $33.83^{\mathrm{a}}$ & $70.17^{\mathrm{ab}}$ \\
\hline $65 \%$ & $33.31^{\mathrm{b}}$ & $43.06^{\mathrm{b}}$ & $66.39^{\mathrm{a}}$ \\
\hline $35 \%$ & $33.53^{\mathrm{b}}$ & $42.61^{\mathrm{b}}$ & $81.94^{\mathrm{c}}$ \\
\hline $15 \%$ & $31.14^{\mathrm{b}}$ & $45.11^{\mathrm{b}}$ & $78.33^{\mathrm{bc}}$ \\
\hline Planting Materials & & & \\
\hline Basal cuttings & $25.57^{\mathrm{a}}$ & $\mathrm{ns}$ & $\mathrm{ns}$ \\
\hline Tip cuttings & $36.39^{\mathrm{b}}$ & $\mathrm{ns}$ & $\mathrm{ns}$ \\
\hline
\end{tabular}

Note: Numbers followed by the same letter are insignificantly different based on Duncan test at a level of 0.05 ; week after treatments (w.a.tr), non-significant (ns).

\section{d. Leaf Area}

The interaction between light intensities and luja plant cutting materials on leaf area variable was found at 2, 4 and 8 w.a.t, except at 6 w.a.tr (Figure 2) and the influence of single factor, which was light intensities, was found only at 10 and 12 w.a.t (Table 4). The light intensity of $35 \%$ with tip cutting $\left(\mathrm{I}_{2} \mathrm{~S}_{2}\right)$ had the largest leaf area compared to other light intensities and cutting treatments at 2 w.a.t. Whereas, leaf area of plants located at light intensity of $65 \%$ with tip cutting $\left(\mathrm{I}_{1} \mathrm{~S}_{2}\right)$ was non-significant different to light intensity of $15 \%$ with the same cutting. Plants originated from basal cutting had small leaf area and it was insignificantly different at all light intensity levels. Plants at 4 w.a.t showed the largest leaf area at light intensity of $65 \%, 35 \%$ and $15 \%$ in tip cutting and it was significantly different to other treatments. Plants exposed to light of $100 \%$ with tip and basal cuttings had small leaf area compared to the use of both cutting types in shaded condition. Plants at 8 weeks after transplanting exposed to light of $65 \%$ and originated from basal cutting had the largest leaf area $\left(\mathrm{I}_{1} \mathrm{~S}_{1}\right)$ and it was significantly different to other treatments, except treatment with light intensity of $15 \%$ in the same cutting $\left(\mathrm{I}_{3} \mathrm{~S}_{1}\right)$. Leaf area at light intensity of $100 \%$ with basal and tip cuttings indicated similar leaf area to those at light intensity of $65 \%$ with tip cutting $\left(\mathrm{I}_{1} \mathrm{~S}_{2}\right)$ and light intensity of $35 \%$ with basal cutting $\left(\mathrm{I}_{2} \mathrm{~S}_{1}\right)$. The growth of plants originated from basal cutting, generally, can be compared to those of tip cutting at 8 w.a.t. Light intensity influence was still visible on leaf area at 10 and 12 w.a.t, where the largest leaf area was observable at light intensity of $35 \%$ and it was significantly different from other treatments at 10 w.a.t. Whilst, light intensity of $15 \%$ was significantly different from other treatments at 12 w.a.tr (Table 4).

Table 4. Influence of Light Intensity on Leaf Area at 10 and 12 weeks after treatment (w.a.tr)

\begin{tabular}{|l|l|l|}
\hline \multirow{2}{*}{ Light Intensity } & \multicolumn{2}{|c|}{ Mean of Leaf Area $\left.\mathbf{( c m}^{\mathbf{2}}\right)$} \\
\cline { 2 - 3 } & $\mathbf{1 0}$ w.a.tr & 12 w.a.tr \\
\hline $100 \%$ & $2464.10^{\text {a }}$ & $2493.20^{\text {a }}$ \\
\hline $65 \%$ & $2186.30^{\text {a }}$ & $2736.10^{\text {a }}$ \\
\hline $35 \%$ & $3057.00^{\mathrm{b}}$ & $3350.20^{\mathrm{b}}$ \\
\hline $15 \%$ & $2100.90^{\mathrm{a}}$ & $3935.20^{\mathrm{c}}$ \\
\hline
\end{tabular}

Note: Numbers followed by the same letter are insignificantly different based on Duncan test at a level of 0.05 ; week after treatment (w.a.tr).

Habitat that supports luja growth is a habitat with a limited light condition (shade plant). It means that the plant is tolerant to low light. Although it could grow in full light 
condition, leaf area increase is hindered due to photoinhibition results in small leaf area and faded color of $100 \%$ light penetration. The success of cuttings to support plant growth is further sustained by light factor. Plants capable of adapting to limited light condition exhibit a wider leaf increase and darker leaf color compared to those plants in full light condition (100\%).
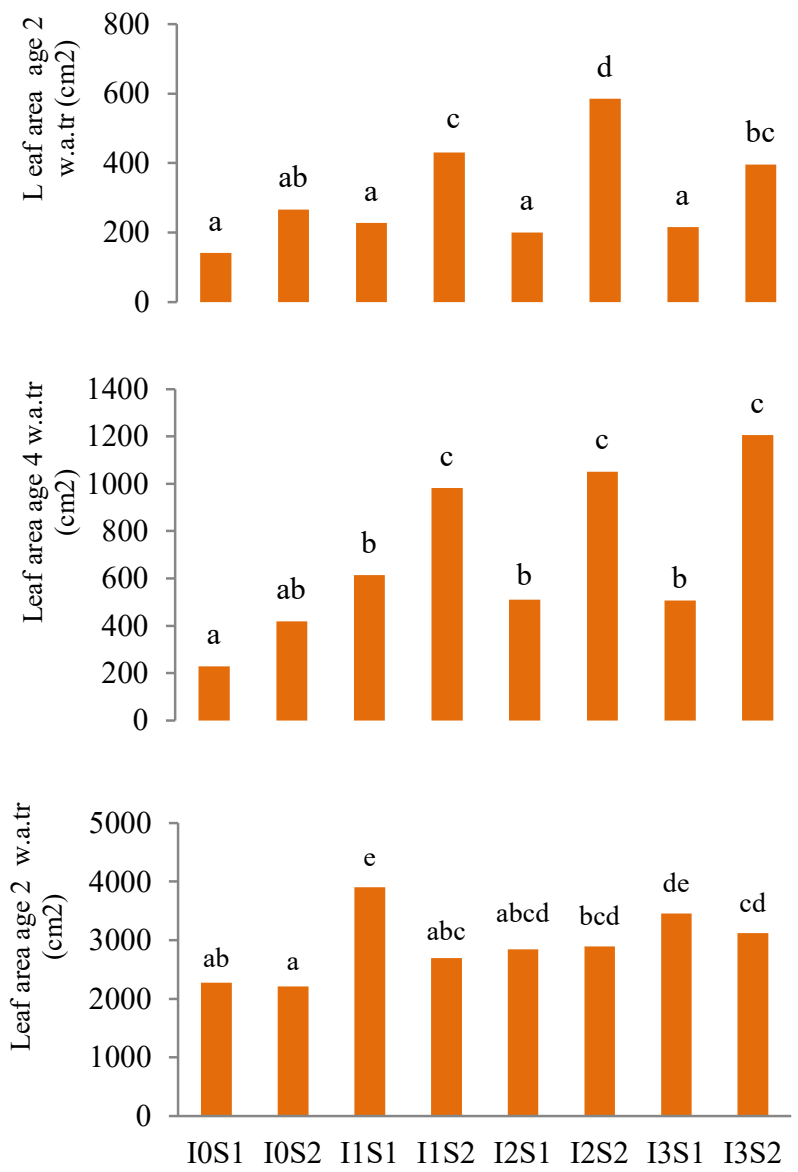

Figure 2. Influence of Interaction between Light Intensities (I) and Planting Materials (S) on Leaf Area at 2, 4 and 8 weeks after transplanting; ; $\mathrm{I}_{0} \mathrm{~S}_{1}$ (Light intensity of $100 \%+$ basal cutting), $\mathrm{I}_{0} \mathrm{~S}_{2}$ (light intensity of $100 \%+$ tip cutting), $\mathrm{I}_{1} \mathrm{~S}_{1}$ (light intensity of $65 \%+$ basal cutting), $\mathrm{I}_{1} \mathrm{~S}_{2}$ (light intensity of $65 \%+$ tip cutting), $\mathrm{I}_{2} \mathrm{~S}_{1}$ (light intensity of $35 \%+$ basal cutting), $\mathrm{I}_{2} \mathrm{~S}_{2}$ (light intensity of $35 \%+$ tip cutting), $\mathrm{I}_{3} \mathrm{~S}_{1}$ (light intensity of $15 \%+$ basal cutting), $I_{3} S_{2}$ (light intensity of $15 \%+$ tip cutting); ; week after treatments, w.a.tr.

Similar result was also found in three varieties of Dracaena sanderiana with large leaf area in 50\%-70\% shade and the higher the shade level, the higher the leaf area in grass species $[23,3]$. Shade benefits temu putih plant since it could increase the number of leaves and leaf area [22] in addition to genetic factors of the plant itself since each plant has light absorption limit in a shaded condition [24]. Stem cuttings from basal and tip parts planted at a full light intensity and shaded indicated different growth. Tip cutting of Plectranthus vettiveroides plant also managed to grow in a shaded condition [7]. Hence, it can be elaborated that Peristrhophe bivalvis Merrill includes in a plant that grows well in low light intensity (sciophytes)

\section{CONCLUSION}

Light intensities and cuttings influenced the changes in luja plant growth phases. Luja grew well at light intensity of $35 \%$. In addition, stem and tip cuttings were generally can be used as planting materials; however, it was tip cuttings that could trigger better growth. Hence, luja could grow in a growing environment with limited light condition (shade-tolerant).

\section{ACKNOWLEDGMENT}

The author expresses gratitude to the University of Khairun for supporting research funding.

\section{REFERENCES}

[1] R. Melati, "Keragaman sumber pewarna nabati yang digunakan Oleh masyarakat Maluku Utara", Prosiding Seminar Nasional Pertanian "Optimalisasi Sumber Daya Lokal Berbasis Riset" Fakultas Pertanian Universitas Ternate, Cetakan I, Ternate.

[2] R.B., Mukhtar, "Influence of Light Intensity on Early Growth of Adansonia digitata (L.). Res. J. Recent Sci. 5(12), pp 5-9, 2016.

[3] J. Sirait,, Luas Daun, Kandungan Klorofil and Laju Pertumbuhan Rumput pada Naungan dan Pemupukan yang Berbeda", JITV 13 (2), pp 109-116, 2008.

[4] P, Ferusn and Arkosiová, "Variability of Chlorophyll Content under Fluctuating Environment " Proceedings of the International Scientific Conference on the Occasion of the 55th Anniversary of the Slovak Agricultural University in Nitra" . Acta fytotechnica et zootechnica (4), pp 123-125, 2001.

[5] Moacyr, B., Dias-Filho, and A. F. C. Júnior, "Growth, Biomass Allocation and Photosynthesis of Rolandra fruticosa (Asteraceae) in Response to Shade", Planta Daninha 18 (1), pp 71-78. 2000.

[6] R.A. Abdullateef, and M. Osman, "Effects of Stem Cutting Types, Position and Hormonal Factors on Rooting in Stevia Rebaudiana Bertoni. Journal of Agricultural Science 4 (1), pp. 49-57, 2012.

[7] P.M. Safeer, S. Sreekumar, P. N. Krishnan, C. K. Biju and. Seeja, "Influence of stem cuttings, spacing, group planting, light, irrigation and harvesting period on yield in Plectranthus 
vettiveroides (K.C. Jacob", Journal of Agriculture and Veterinary Science 6 (3), pp 47-53, 2013.

[8] S. E., Rozali, K. A. Rashid and R. Farzinebrahimi,, "Effects of Shading Treatments on Pigmentation and Inflorescence Quality of Calathea crotalifera Bracts Int. J. Agric. Biol., (18), pp 549-556, 2011.

[9] R.P. Mauro, A. Occhipinti, A. M. G. Longo and G. Mauromicale, "Effects of Shading on Chlorophyll Content, Chlorophyll Fluorescence and Photosynthesis of Subterranean Clover" Journal of Agronomy and Crop Science (197), 57-66, 2011.

[10] G Zervoudakis, G., G. Salahas, G. Kaspiris dan E. Konstantopoulo, "Influence of Light Intensity on Growth and Physiological Characteristics of Common Sage (Salvia officinalis L.)", Braz. Arch. Biol. Technol 55(1), pp 89-95. 2012.

[11] K.G. McAlpine and L. K. Jesson, "Biomass Allocation, Shade Tolerance and Seedling Survival of the Invasive Species Berberis darwinii (Darwin's barberry)", New Zealand Journal of Ecology 31(1),1-12, 2007.

[12] A. Devkota and P. K. Jha, "Effects pf Deifferent Light Level on the Trairs and Yield of Centella asiatica," Middle-East Journal of Scientific Research 5 (4), pp 226-230, 2010.

[13] R. Santelices, S. Espinoza and A. M. Cabrera, "Effects of Shading and Slow Release Fertilizer on Early growth of Nothofagus leonii Seedlings from Its Northernmost Distribution in Central Chile", Bosque 36 (2), pp 179-185, 2015.

[14] W. Yulistyani, D. S. Sobarna dan A. Nuraini, "Pengaruh Jenis Stek Batang dan Komposisi Media Tanam terhadap Pertumbuhan Bibit Tanaman Ara (Ficus carica L.)", Agric. Sci. J. 1 (4), pp 215-224, 2014.

[15] N. Musyarofah, S. Susanto, S. A. Aziz, dan S. Kartosoewarno, "Respon Tanaman Pegagan (Centella asiatica L. Urban) Terhadap Pemberian Pupuk Alami di Bawah Naungan", Bul. Agron, 35 (3), pp 217 - 224, 2007.

[16] [16] L. Widiastuti, Tohari and E. Sulistyaningsih, "Pengaruh Intensitas Cahaya dan Kadar Daminosida terhadap Iklim Mikro dan Pertumbuhan Tanaman Krisan dalam Pot" Ilmu Pertanian 11 (2), pp 53-42, 2004.

[17] M. S. Hlatshwayo and P. K. Wahome, "Effects of Shading on Growth, Flowering and Cut Flower Quality in Carnation (Dianthus caryohyllus)", J. Agric. Soc. Sci., ( 6): pp. 34-38, 2010.

[18] C.T., H. Mardi, Setiado and K. Lubis, "Pengaruh Asal Stek dan Zat Pengatur Tumbuh Atonik Terhadap Pertumbuhan dan Produksi Dua Varietas Ubi jalar (Ipomoea batatas L.) Lamb." Jurnal Agroekoteknologi 4 (4), pp. 2341-2348, 2016.
[19] Zheng, Y., W. Jiang, E. N. Silva, L. Mao, D.B. Hannaway dan H. Lu, "Optimization of shade condition and harvest time for Dendrobium candidum plants basedon gas exchange, alkaloids and polysaccharides contents", Plants Omics Journal 5 (3), pp 253-260, 2012.

[20] R. Fauzi, Meiriani dan A. Barus, "Pengaruh Persentase Naungan Terhadap Pertumbuhan Bibit Mucuna bracteata D.C. Asal Setek dengan Konsentrasi IAA yang Berbeda",Jurnal Agroekoteknologi 4 (3), pp 2114 - 2126, 2016.

[21] S. L. Brito, C. L. Pinheiro, F. C. B. Nogueira, S. M. Filho and D. M. S. Matos de, "Influence of light on the initial growth of invasive Cryptostegia madagascariensis Bojer in the Brazilian semiarid region," Acta Sci. Bio. Sciences 37 (3), pp. 385-392, 2015.

[22] B.H. Buntoro, R. Rogomulyo and S. Trisnowati, "Pengaruh Takaran Pupuk Kandang dan Intensitas Cahaya Terhadap Pertumbuhan dan Hasil Temu Putih (Curcuma zedoaria L.)," Vegetalika 3 (4), pp. 29 - 39, 2014.

[23] S' Srikrishnah, S.E. Peiris and S. "Sutharsan, "Effect of Shade Levels on Leaf Area and Biomass Production of Three Varieties of Dracaena sanderiana L. in the Dry Zone of Sri Lanka" Tropical Agricultural Research 23 (2), pp 142-151, 2012.

[24] H., Sevik, D. Guney, H. Karakas and G. Aktar. "Change to Amount of Chlorophyll on Leaves Depend on Insolation in Some Landscape Plants", 3 (3), PP 1057-164, 2012. 